\title{
Wprowadzenie Deprywatyzacja szkolnictwa wyższego w Polsce. Co oznacza i jakie niesie konsekwencje?
}

Pojęcie „deprywatyzacja” nie było dotąd stosowane w międzynarodowych badaniach szkolnictwa wyższego; uważamy, że w polskim przypadku jest ono niezwykle przydatnym narzędziem teoretycznym. Procesy deprywatyzacji dominują w Polsce od $2006 \mathrm{r}$. i przeciwstawiamy je procesom prywatyzacji dominującej w latach 1990-2005. Zarazem lata 1990-2006 to epoka ekspansji szkolnictwa wyższego, a okres po 2006 r. - to epoka jego implozji, czyli systematycznego kurczenia się. Głównym motorem zmian jest zmieniająca się demografia, ale również spadający od 2010 r. współczynnik skolaryzacji. Polska ma coraz mniej studentów, mniej studentów płacących za studia oraz mniej studentów w sektorze prywatnym natomiast procesy zachodzące globalnie są dokładnie odwrotne. Deprywatyzacja oznacza procesy zachodzące w obu sektorach i w całym systemie: upraszczając, maleje rola wymiarów prywatnych, a rośnie rola wymiarów publicznych (dlatego „deprywatyzacja” oznacza zarazem „republicyzacje”, tj. ponowne upublicznienie). Polski system przechodzi zatem obecnie ponowne upublicznienie - w coraz większym stopniu opiera się na publicznych instytucjach, publicznym finansowaniu badań naukowych oraz opłacanych z podatków studentach sektora publicznego. Ujmowany w dualistycznych kategoriach prywatne/publiczne, staje się zatem jednocześnie coraz bardziej zreprywatyzowany i ponownie upubliczniony (aspekty teoretyczne: Kwiek 2016).

Według kilku zgodnych ze sobą scenariuszy dotyczących przyszłej liczby studentów (Vincent-Lancrin 2008: 45; Antonowicz i Godlewski 2011: 10-14; IBE 2011: 110-111; EY/IBNGR 2010: 20), można się spodziewać, że liczba studentów w Polsce do 2025 r. może zmniejszyć się o 55-65\% w stosunku do 2005 r. i spaść do poziomu 1,26 mln. Naszym zdaniem liczba ta może być jeszcze mniejsza - system 
może skurczyć się do poziomu 1 mln studentów, a więc o połowę w stosunku do szczytu z 2006 r., a zdecyduje o tym skumulowany wpływ demografii i emigracji zarobkowej. W teoretycznym kontekście prywatyzacji/deprywatyzacji oznacza to jedno: nie tylko skończyła się epoka ekspansji w szkolnictwie wyższym, lecz także dominujące do niedawna procesy prywatyzacji znajdują się w odwrocie.

Deprywatyzacja to polski kontrtrend stojący w opozycji wobec globalnych trendów prywatyzacyjnych, szczególnie zaś wobec globalnego rozwoju sektora prywatnego i globalnie rosnącej zależności od mechanizmów współodpłatności za studia w instytucjach publicznych (Heller i Callender 2013; Marcucci 2013; Altbach, Reisberg i Rumbley 2010: 75-84, Johnstone 2012; Johnstone i Marcucci 2010). Zachodzące w Polsce procesy są szczególnie ważne w perspektywie porównawczej poza częścią krajów postkomunistycznej Europy (Bułgaria, Rumunia czy Estonia), jak się wydaje, nie zachodzą one w tej chwili nigdzie indziej w świecie.

Deprywatyzacja zachodzi dziś jedynie w postkomunistycznej Europie, ponieważ wyłącznie w tej części świata mieliśmy do czynienia z trwającym ponad dwie dekady rozwojem prywatnego szkolnictwa wyższego (typu ,finansowo niezależnego od państwa”, czyli independent private w terminologii statystycznej OECD), z mocno ograniczonym dostępem do edukacji wyższej w dekadach poprzedzających upadek komunizmu oraz ze społeczeństwami, które przechodzą szybszy niż gdziekolwiek indziej w Europie proces starzenia się (związany m.in. z dramatycznie niskim wskaźnikiem dzietności).

Deprywatyzacja jest procesem zmieniającym zastaną równowagę między tym, co publiczne, a tym, co prywatne, w stronę tego pierwszego; jest możliwym powrotem do normalności w tych częściach Europy, gdzie tym, co „normalne” tradycyjnie, było przede wszystkim publiczne i bezpłatne (czyli oparte na podatkach) szkolnictwo wyższe (w polskim przypadku procesem napędzanym przez demografię, ale w innych częściach świata mogłyby to być mechanizmy np. o podłożu czysto ideologicznym czy czysto finansowym). W efekcie tego obecna dynamika publiczne/prywatne w postkomunistycznej Europie różni się znacząco zarówno od tej samej dynamiki w Europie Zachodniej, jak i w ujęciu globalnym. Dynamika publiczne/prywatne w krajach Europy Zachodniej zawsze była odmienna, gdyż prywatne szkolnictwo wyższe oraz opłaty za czesne nie są tam dominującą - ani nawet szczególnie istotną - cechą szkolnictwa wyższego (o hybrydyzacji publicznego i prywatnego w szkolnictwie wyższym i konieczności wychodzenia poza ten dualizm w perspektywie uniwersytetu jako dobra wspólnego: Szadkowski 2015).

Udział studentów płacących czesne w całej populacji studentów był w okresie ekspansji z lat 1990-2005 wysoki (rósł od 46,6\% w 1995 r. do 62,8\% w 2000 r. i spadł nieznacznie do 58,9\% w 2005 r.). Obecnie, w okresie implozji systemu, udział tych studentów systematycznie spada, do 40\% w 2015 r., a można się spodziewać, że spadnie jeszcze o połowę do 2022 r. (MNiSW 2012: 8). W sektorze publicznym liczba studentów ponoszących opłaty za studia zmniejszyła się o po- 
Wykres 1. Udział studentów wnoszących opłaty za studia w obu sektorach (publicznym i prywatnym razem), w latach 2006-2015 (w \%) oraz ich liczba (w tys.)

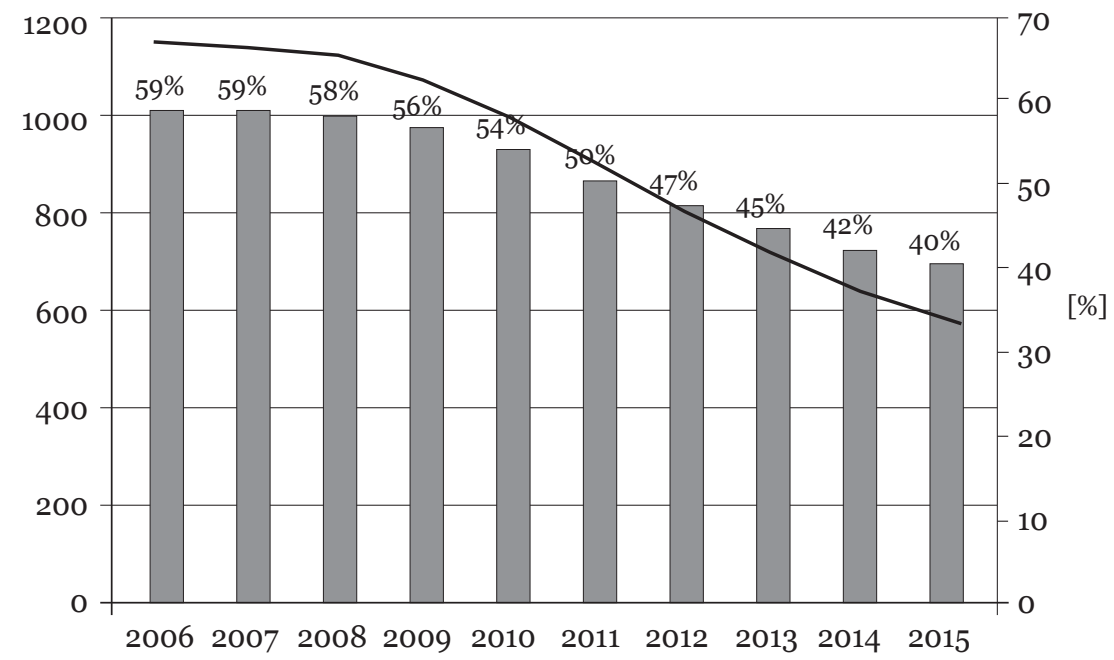

Źródło: opracowanie własne na podstawie danych GUS (2016 i wcześniejsze wydania).

Wykres 2. Liczba studentów wnoszących opłaty za studia: w sektorze publicznym (lewa kolumna) i prywatnym (wszyscy studenci, prawa kolumna) w latach 2006-2015 (w tys.)

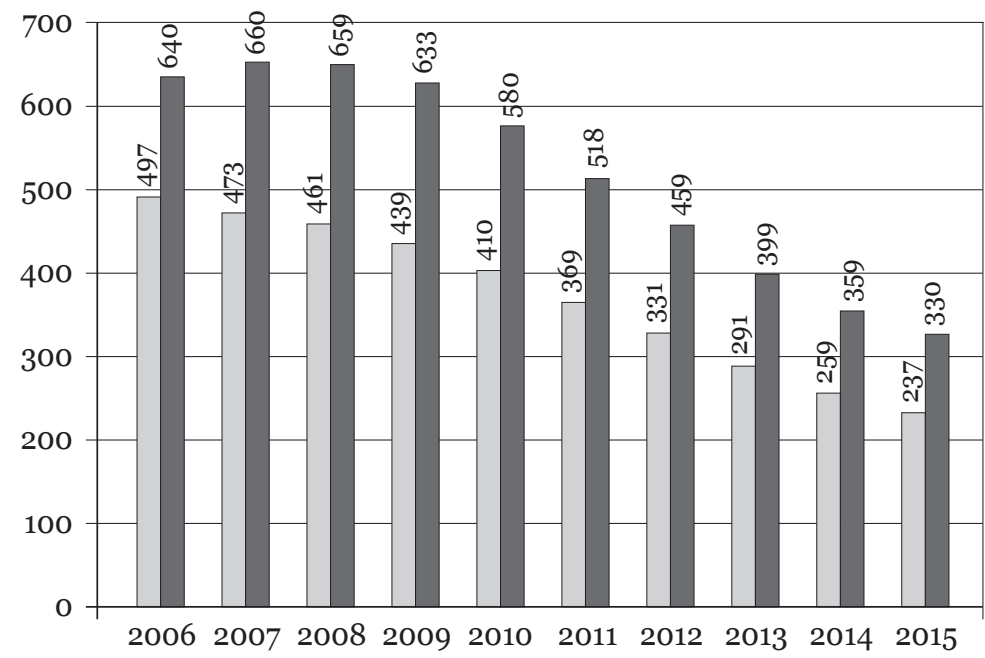

Źródło: opracowanie własne na podstawie danych GUS (2016 i wcześniejsze wydania). 
łowę. Procesy te wywołuja zarazem poważne konsekwencje finansowe - systematycznie maleje wielkość (i procentowy udział) środków prywatnych, a rośnie udział środków publicznych (co jest jednym z wymiarów deprywatyzacji systemu, zob. wykresy 1 i 2).

Chociaż pula kandydatów na studia zmniejsza się z roku na rok, pula dostępnych miejsc opłacanych z podatków stabilizuje się lub tylko nieznacznie zmniejsza. Kurcząca się liczba studentów oznacza mniej stabilne perspektywy akademickiego zatrudnienia - dlatego każda instytucja publiczna oraz każdy jej wydział koncentruje dziś swoją strategię na utrzymaniu stabilnego poziomu naborów na studia (może to zmienić nowy algorytm obliczania dotacji statutowej, zob. proponowane kierunki reform: Antonowicz i in. 2016; Kwiek i in. 2016).

Prędkość zachodzących zmian w składzie ogółu studentów według źródeł finansowania (oraz według sektora) jest bezprecedensowa. W grze o sumie zerowej w epoce implozji niewątpliwie zyskuje sektor publiczny. Szansą na rekompensatę strat w naborze studentów jest dla sektora prywatnego przyjmowanie na masową skalę studentów zagranicznych. Scenariusz ten jednak w odniesieniu do całości tego sektora pozostaje bardzo mało prawdopodobny. Obecny poziom umiędzynarodowienia (2015) należy do najniższych w Europie i wynosi 4,07\% (57,1 tys. studentów), chociaż systematycznie rośnie. Przyszłość prywatnego szkolnictwa w Polsce (oraz dynamiki publiczne - prywatne w grze o sumie zerowej przy malejącej puli polskich kandydatów na studia oraz ograniczonym napływie kandydatów na studia z zagranicy) jest powiązana w Polsce z ujemnym trendem demograficznym silniej niż w pozostałych krajach Unii Europejskiej.

Zasada selektywności w dostępie do studiów jest konfrontowana z zasadą stabilności akademickich miejsc pracy (wynikającą z presji na podtrzymywanie ich liczby na stałym poziomie). Jak dotąd zasada stabilności dominuje we wszystkich rodzajach instytucji i we wszystkich obszarach studiów, a wzmacnia ją silna kolegialność akademicka (Kwiek 2015d). Proces ten ma również negatywne konsekwencje dla wielkości i poziomu produkcji wiedzy naukowej oraz średniej produktywności naukowej kadry akademickiej (niezwykle niskich z europejskiej perspektywy porównawczej; o wpływie umiędzynarodowienia na produktywność badawczą w Europie i w Polsce zob. Kwiek 2015b, a o podziale młoda kadra/starsza kadra i ich ujęciu istoty pracy naukowej - Kwiek 2015c; 2015f).

Umasowienie szkolnictwa wyższego było bardzo silnie związane z procesami „zewnętrznej” i „wewnętrznej” prywatyzacji (Kwiek 2010). Zewnętrzna prywatyzacja szkolnictwa wyższego oznacza wzrost liczby prywatnych instytucji oraz liczby studentów w tym sektorze, natomiast jego wewnętrzna prywatyzacja wiąże się ze wzrostem liczby studentów płacących za studia oraz wzrostem nominalnym i/lub proporcjonalnym przychodów z opłat za czesne w publicznym szkolnictwie wyższym (zob. rozważania na temat prywatyzacji: Levy 1986; 1992; Geiger 1986; 1988; Williams 1996; Johnstone 2009; Marginsom 1997; 2007; Levine 2001; Sa- 
lerno 2004; Priest i St. John 2006; Morphew i Eckel 2009; szerzej o Polsce: Kwiek 2015a).

Uważamy, że tak jak „prywatyzacja” była podstawową cechą epoki ekspansji (1990-2005) systemu polskiego szkolnictwa wyższego, tak „deprywatyzacja” staje się stopniowo istotną cechą epoki implozji tego systemu (2006-2025). W Polsce rozwój sektora publicznego od 2006 r. jest powiązany z jego stopniową deprywatyzacją (a nie, jak w większości systemów pozaeuropejskich, jego wewnętrzną prywatyzacją). Oznacza to, że coraz większa liczba studentów sektora publicznego jest rekrutowana na miejsca na studiach stacjonarnych (a więc bez opłat za czesne), a coraz mniej studentów tego sektora podejmuje studia niestacjonarne (czyli z opłatami za czesne). W wyjątkowym - z perspektywy globalnej - polskim przypadku istnieje stabilna lub rosnąca liczba studentów finansowanych z podatków (oraz stabilne bądź rosnące finansowanie publiczne) w sektorze publicznym, bez wyrażonego wprost (ale czytelnego w kategoriach praktycznych) rządowego zamiaru wspierania przetrwania sektora publicznego w trudnych pod względem demograficznym czasach.

Zmiany w systemie można traktować jako stopniową ewolucję w ramach czterech kategorii systemu (czwarta, ostatnia, jest kategorią jedynie prognozowaną, choć o dużym stopniu prawdopodobieństwa):

- system w pełni publiczny, funkcjonujący w okresie komunistycznym (do 1989 r.),

- system podwójny (mieszany) publiczno-prywatny w okresie umasowienia i ekspansji z lat 1990-2005 (z wyraźną dominacją sektora publicznego pod względem liczby studentów oraz prestiżu),

- system podlegający deprywatyzacji w okresie przejściowym, w trakcie którego sektor prywatny i prywatne finansowanie w sektorze publicznym odgrywają coraz mniejszą rolę (2006-2015 oraz, prognostycznie, 2016-2024),

- system zdeprywatyzowany, z marginalną rolą sektora prywatnego z udziałem studentów na poziomie maksymalnie 10-15\% oraz dominującą rolą publicznego finansowania (2025 r. i później).

Procesy deprywatyzacji można uznać za stopniowy powrót instytucji publicznych do środowiska, w którym finansowanie jest przede wszystkim publiczne - malejąca liczba studentów płacących czesne oznacza malejący udział opłat za czesne w całkowitym budżecie operacyjnym instytucji publicznych. Trend ten potwierdzają coroczne sprawozdania finansowe polskich uczelni z lat 2006-2015; przychody z opłat za czesne zmniejszają się systematycznie nawet na najbardziej prestiżowych uniwersytetach (w latach 2011-2015 roczne przychody UW z tego tytułu zmalały ze 153 do 102 mln zl, UJ ze 107 - w 2012 r. - do 101 mln, Uniwersytetu Gdańskiego z $56 \mathrm{mln}$ do $44 \mathrm{mln}$, UAM z $66 \mathrm{mln}$ do $46 \mathrm{mln}$, UMK z $42 \mathrm{mln}$ do $34 \mathrm{mln}$ i Uniwersytetu Wrocławskiego z $69 \mathrm{mln}$ do $46 \mathrm{mln}$ ). Na wykresie 3 pokazujemy zmiany poziomu przychodów $\mathrm{z}$ opłat za czesne w obu sektorach. W analizowanym okresie spadki wystąpiły z opóźnieniem - w sektorze publicznym między 
Wykres 3. Przychody z opłat za czesne w sektorze publicznym i prywatnym (w mln PLN) w latach 2006-2015 (lewa kolumna, jasna - sektor prywatny)

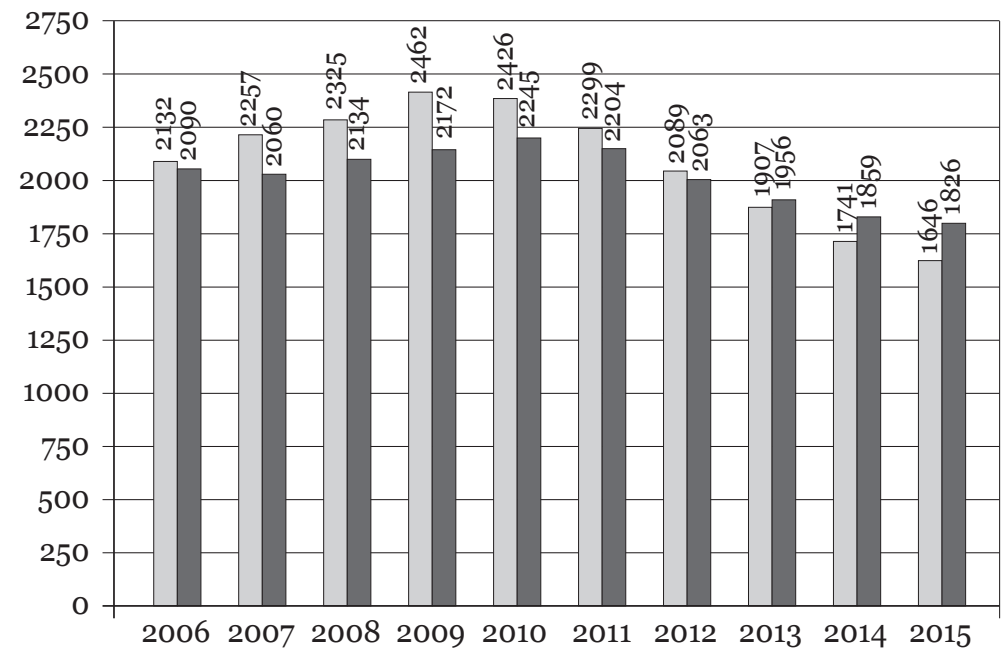

Źródło: opracowanie własne na podstawie danych GUS (2016 i wcześniejsze wydania).

Wykres 4. Udział przychodów prywatnych (z kształcenia) w sektorze publicznym w budżecie operacyjnym sektora publicznego (szara linia, w \%) oraz udział przychodów z opłat za czesne (w sektorze prywatnym i publicznym razem) w całkowitym budżecie operacyjnym w obu sektorach (czarna linia, w \%) w latach 2006-2015

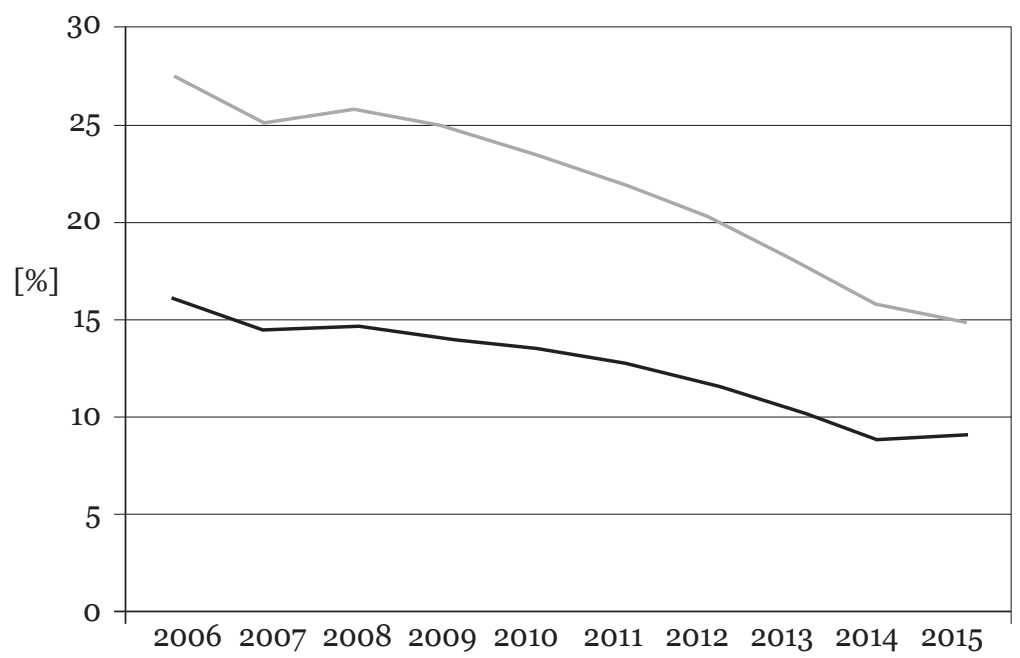

Źródło: opracowanie własne na podstawie danych GUS (2016 i wcześniejsze wydania). 
2010 a 2015 r. zmniejszyły się o ponad 400 mln zł rocznie, a w o wiele mniejszym sektorze prywatnym w latach 2009-2015 były jeszcze większe i wyniosły ponad 800 mln zł rocznie. Również po raz pierwszy w analizowanej dekadzie przychody prywatne z czesnego w 2013 r. były większe w sektorze publicznym niż prywatnym - i luka ta systematycznie się powiększa. Udział przychodów z opłat za czesne (w obu sektorach łącznie) w całkowitym budżecie operacyjnym obu sektorów latach 2006-2015 zmniejszył się z 27,5 do 14,7\%, czyli o prawie połowę. Podobnie zmniejszył się udział przychodów prywatnych (z kształcenia) w sektorze publicznym w budżecie operacyjnym tego sektora: z 16,2 do 8,6\%. Oba procesy pokazujemy na wykresie 4.

$\mathrm{W}$ polskim sektorze publicznym (w trybie stacjonarnym) opłaty za czesne w ogóle nie występują, wobec czego omawiana luka ma dziś maksymalne rozmiary i jest dość trwała ze względu na mocno ugruntowaną tradycję szkolnictwa wyższego finansowanego wyłącznie z budżetu państwa, tradycję silną w całym regionie oraz w Europie Zachodniej. Polityka zmniejszania owej luki przez wprowadzanie mechanizmów współodpłatności za studia wydaje się w polskim kontekście w perspektywie średnioterminowej - mało prawdopodobna. Globalna argumentacja na rzecz współodpłatności zakłada, że koszty kształcenia w skali całego systemu nieustannie rosną, stają się coraz większym ciężarem dla państwa i dlatego powinny rozkładać się między państwo a studentów, czego nie spodziewamy się w Polsce w najbliższej dekadzie z powodów demograficznych.

Dlatego też nie przewidujemy, aby dwie potężne globalne agendy prywatyzacji - pierwsza dotycząca rosnącego poziomu współodpłatności za studia i druga dotycząca przyspieszonego rozwoju sektora prywatnego - znalazły swoje przełożenie na zmiany w polskim prawodawstwie, szczególnie przy obecnym kierunku zmian w UE, w której obie te agendy są dość słabe.

Z perspektywy historycznej zjawisko, który moglibyśmy określić mianem „eksperymentu prywatyzacyjnego" w szkolnictwie wyższym w Polsce, można interpretować jako zaledwie przejściowe: niezwykle intensywne, ale krótkotrwałe. Można je oceniać jako przydatny eksperyment w okresie przyspieszonego - przez bezprecedensowe wydarzenia historyczne - umasowienia, eksperyment już mniej użyteczny w trakcie dojrzewania systemu i wreszcie jako eksperyment o marginalnej użyteczności w okresie dzisiejszego i przyszłego powszechnego dostępu do szkolnictwa wyższego. Prywatne szkolnictwo wyższe przeżyło fazę ogromnego wzrostu i mocnej stabilizacji w epoce ekspansji edukacyjnej (1990-2005), a obecnie przeżywa trudną fazę schyłkową: przypomnijmy, że w 2014 r. 144 uczelnie prywatne (czyli ich połowa - 49,66\%) miały mniej niż 500 studentów, a 260 uczelni, czyli prawie 90\% (86,21\%) miało mniej niż 2 tys. studentów. Jak w przypadku każdego eksperymentu społecznego (i edukacyjnego) podejmowanego na dużą skalę, jego konsekwencje trudno jeszcze dzisiaj ocenić. Z pewnością okres implozji systemu przyniesie konsolidację części tego sektora i wzmocnienie półelitarnych (semi- 
-elite) uczelni zlokalizowanych w największych ośrodkach akademickich, przede wszystkim w Warszawie.

Polska, po ponad dwóch dekadach eksperymentów z prywatyzacją, pozostaje zarazem w obrębie szerszych społecznych wyborów dotyczących finansowania szkolnictwa wyższego, które dominują w Europie Zachodniej. Na zachodzące w praktyce zmiany nie miały jednak żadnego wpływu przekonania ideologiczne: Polska nie stała się niespodziewanie w ostatnich latach bliższa europejskim modelom społecznym - zadecydowała nie polityka i stojąca za nią ideologia, ale demografia. Zmieniająca się demografia, jako bezlitosny czynnik poniekąd zewnętrzny i niepoddający się ideologicznej i politycznej manipulacji, może właśnie na naszych oczach zmieniać system szkolnictwa wyższego na znany nam dotąd głównie z Europy Zachodniej. Deprywatyzacja systemu - a tym samym jej odwrotna strona, republicyzacja - sprawia, że stajemy się bliżsi systemom zachodnioeuropejskim. Zmiany te obserwujemy z dużą życzliwością jako jeden z elementów szerszych procesów upodabniania się Polski do rozwiniętego świata zachodniego (chociaż nie anglosaskiego).

Dynamiczny rozwój sektora prywatnego w szkolnictwie wyższym przekształca się zatem stopniowo (a bierzemy tu pod uwagę najbliższą dekadę) w proces jego słabnięcia, a może zaniku; ogólny trend prywatyzacji systemu jako całości z okresu ekspansji - zmienia się w ogólny trend jego deprywatyzacji. Do tradycyjnego katalogu historycznych, politycznych i gospodarczych czynników różnicujących ich przyszłe trajektorie powinniśmy dodać kolejny czynnik, a mianowicie długoterminowe trendy demograficzne, których rola pozostaje jak dotąd silnie niedoszacowana w globalnych i europejskich badaniach nad szkolnictwem wyższym. Tym samym do katalogu użytecznych pojęć warto dodać pojęcie „deprywatyzacji” - mimo że cały świat w aspekcie teoretycznym oraz w praktyce edukacyjnej koncentruje się na pojęciu „prywatyzacji”.

\section{Podziękowania}

Wydanie tego numeru nie udałoby się bez wsparcia udzielonego przez Narodowe Centrum Nauki (NCN) w ramach projektu MAESTRO (Program Międzynarodowych Badań Porównawczych Szkolnictwa Wyższego DEC-2011/02/A/HS6/00183) oraz przez Fundację na Rzecz Nauki Polskiej (FNP) w ramach projektu MISTRZ (subsydium profesorskie - umowa 5/2015). Wyrażam niniejszym swoją głęboką wdzięczność obydwu instytucjom.

\footnotetext{
${ }^{1}$ Pełna prezentacja tych idei w tekście: „Prywatyzacja i deprywatyzacja: od ekspansji (1990-2005) do implozji (2006-2025) systemu szkolnictwa wyższego w Polsce”. Nauka. 1, 39-67, a idei teoretycznych w: Kwiek 2016.
} 


\section{Literatura}

Altbach, Ph.G., Reisberg, L., Rumbley, L. E. (2010). Trends in Global Higher Education. Tracking an Academic Revolution. Rotterdam - Boston - Taipei: Sense.

Antonowicz, D., Godlewski, B. (2011). Demograficzne tsunami. Raport Instytutu Sokratesa na temat wpływu zmian demograficznych na szkolnictwo wyższe do 2020 roku. Warszawa: Instytut Sokratesa.

Antonowicz, D., Brdulak, J., Hulicka, M., Jędrzejewski, T., Kowalski, R., Kulczycki, E., Szadkowski, K., Szot, A., Wolszczak-Derlacz, J., Kwiek, M. (2016). Reformować? Nie reformować? Szerszy kontekst zmian w szkolnictwie wyższym. Nauka. 4: 7-33.

EY/IBNGR (2010). Strategia rozwoju szkolnictwa wyższego do 2020 roku. Warszawa: MNiSW. Geiger, R.L. (1986). Private Sectors in Higher Education. Structure, Function, and Change in Eight Countries. Ann Arbor: The University of Michigan Press.

Geiger, R.L. (1988). Conference Report: Privatization of Higher Education. Princeton: International Council for Educational Development.

Gumport, P.J., Iannozzi, M., Shaman, S., Zemsky, R. (1997). The United States Country Report: Trends in Higher Education from Massification to Post-Massification. W: Academic Reforms in the World: Situation and Perspective in the Massification Stage of Higher Education. RIHE International Seminar Reports no. 10 (57-93). RIHE: Hiroshima University.

GUS (2016). Szkoły wyższe i ich finanse w 2015 r. Warszawa: Główny Urząd Statystyczny.

Heller, D.E., Callender, Claire (red.) (2013). Student Financing of Higher Education. A Comparative Perspective. Routledge: New York.

IBE (2011). Społeczeństwo $w$ drodze do wiedzy. Raport o stanie edukacji 201o. Warszawa: Instytut Badań Edukacyjnych.

Johnstone, D. B. (2012). The Costs of Higher Education. W: Ph.G. Altbach (red.). International Higher Education. An Encyclopedia. T. 1 (59-89). New York - London: Garland Publishing.

Johnstone, D. B. (2009). Financing Higher Education: Cost-Sharing in International Perspective. Rotterdam: Sense.

Johnstone, D. B., Marcucci, P. (2010). Financing Higher Education Worldwide. Who Pays? Who Should Pay? Baltimore: The Johns Hopkins University Press.

Kwiek, M. (2010). Creeping Marketization: Where Polish Private and Public Higher Education Sectors Meet. W: R. Brown (red.). Higher Education and the Market (135-146). New York: Routledge.

Kwiek, M. (2015a). Uniwersytet $w$ dobie przemian. Instytucje $i$ kadra akademicka $w$ warunkach rosnacej konkurencji. Warszawa: Wyd. Naukowe PWN.

Kwiek, M. (2015b). The Internationalization of Research in Europe. A Quantitative Study of 11 National Systems from a Micro-Level Perspective. Journal of Studies in International Education. 19(2): 341-359.

Kwiek, M. (2015c). Academic generations and academic work: Patterns of attitudes, behaviors and research productivity of Polish academics after 1989. Studies in Higher Education. 40(8): 1354-1376.

Kwiek, M. (2015d). The unfading power of collegiality? University governance in Poland in a European comparative and quantitative perspective. International Journal of Educational Development. 43 : 77-89. 
Kwiek, M. (2015f). Młoda kadra: różnice międzypokoleniowe w pracy naukowej i produktywności badawczej. Czym Polska różni się od Europy Zachodniej? Nauka. 3: 51-88.

Kwiek, M. (2016). Deprivatization in Higher Education: A Conceptual Approach. Higher Education (online: 18.08.2016). DOI: 10.1007/s10734-016-0047-3.

Kwiek, M., Antonowicz, D., Brdulak, J., Hulicka, M., Jędrzejewski, T., Kowalski, R., Kulczycki, E., Szadkowski, K., Szot, A., Wolszczak-Derlacz, J. (2016). Projekt założeń do ustawy Prawo o szkolnictwie wyższym. Poznań: Wyd. Naukowe WNS UAM.

Levine, A. (2001). Privatization in Higher Education. www.nga.org.

Levy, D.C. (1986). "Private" and "Public": Analysis Amid Ambiguity in Higher Education. W: D.C. Levy (red.). Private Education. Studies in Choice and Public Policy (120-147). Oxford: Oxford University Press.

Levy, D.C. (1992). Private Institutions of Higher Education. W: The Encyclopedia of Higher Education, red. B.R. Clark, G. Neave. T. 2 (1183-1194). Oxford: Pergamon Press.

Marcucci, P. (2013). The Politics of Student Funding Policies from a Comparative Perspective. W: D. E. Heller, C. Callender (red.). Student Financing of Higher Education. A Comparative Perspective (9-31). Routledge: New York.

Marginson, S. (1997). Markets in Education. St. Leonards: Allen \& Unwin.

Marginson, S. (2007). The Public/Private Divide in Higher Education: A Global Revision. Higher Education. 53: 307-333.

MNiSW (2012). Projekt założeń projektu ustawy o zmianie ustawy - Prawo o szkolnictwie wyższym oraz niektórych innych ustaw. Warszawa: MNISW.

Morphew, Ch.C., Eckel, P.D. (red.) (2009). Privatizing the Public University. Perspectives from Across the Academy. Baltimore: The Johns Hopkins University Press.

Priest, D. M., St. John, E.P. (red.) (2006). Privatization and Public Universities. Bloomington: Indiana University Press.

Salerno, C. (2004). Public Money and Private Providers: Funding Channels and National Patterns in Four Countries. Higher Education. 48: 101-130.

Szadkowski, K. (2015). Uniwersytet jako dobro wspólne. Podstawy krytycznych badań nad szkolnictwem wyższym. Warszawa: Wyd. Naukowe PWN.

Vincent-Lancrin, S. (2008). What is the Impact of Demography on Higher Education Systems? A Forward-looking Approach for OECD Countries. W: Higher Education to 2030. T. 1: Demography (41-103). Paris: OECD.

Williams, G. (1996). The Many Faces of Privatization. Higher Education Management. 8(3): 39-56.

Yonezawa, A. , Kim, T. (2008). The Future of Higher Education in the Context of a Shrinking Students Population: Policy Challenges for Japan and Korea. W: Higher Education to 2030. T. 1: Demography (199-220). Paris: OECD.

CYTOWANIE: Kwiek, M. (2016). Wprowadzenie. Deprywatyzacja szkolnictwa wyższego w Polsce. Co oznacza i jakie niesie konsekwencje? Nauka i Szkolnictwo Wyższe. 2(48): 7-16. DOI: 10.14746/ nisw.2016.1.o. 